の生体指標との関㖶を報告した，Pb-P は Pb-U・Pb-B と相関性が良いこと，また ALAD・ALA-U・CP-U は $\mathrm{Pb}-\mathrm{P}$ より $\mathrm{Pb}-\mathrm{B}$ との相関が良いことを示した。 $\mathrm{Pb}-\mathrm{P}$ と $\mathrm{Pb}-\mathrm{U}$ との良い相関性は鈆の尿中排泄性濃度こう配 によることを意味することを示唆した。これらのことか ら，鉛の生体影響をみる指標の選定に，これらの点をふ ま光，選定すべきことが大切であると示された.

152: 高濃度暴露者耴いて動員鉛量 と血液鉛, 尿中 鉛などがむしろ逆相関を示すようなデータが得られたこ とについて質問が市り, 暴露終了後, 検查時点までの時 間経過が問題なのではないか，また例数が少ない点もあ ろうと答兄た．血液鉛 $60 \mu \mathrm{g} / 100 \mathrm{~g}$ 飞相当する動員鉛量 を計算するのにどのよらな関係式を使用したかとの問に 対し, 回帰直線を使ったと答えた。次の演題では, 血液 鉛と動員鉛の間に直線でなく曲線関係がみられていると の指摘が㐫った。

153 ：可動員鉛量を推定することの実用的意義が質問 され，24 時間鉛動員試験值が可動員鉛の約 $14 \%$ 程度で あること，総佮闪鈶量に比べれば可動員鉛量は著しく小 さいことなどがある程度定量的に推定できる点に意義が あるらと答党た。

（維括討論）充分に時間を取れなかったが，血漿鉛濃 度の意味をめぐって活発な討議があった。

134. 鉛作叢者の NK 活性 (II)

加藤芳郎，毛利靖彦，鳥海久雄 小䈃 築，小森羕隆，皿井 進 (大同病院)

種々の金属イオンのヒトNK活性に対する影響の作用 機序の検討と，金属暴露者として鉛作業者を対像として 血中鉛と NK 活性を測定し影響を検討しな.

〈才法, 対象〉 末梢静脈血中リンパ球と, K 562 細

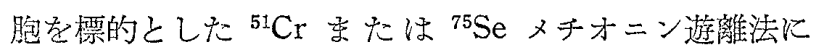
てNK 活性を浿定した．24 時間の金属イオンを含む培 盖液で培養後洗浄し，リンハ球化対する直接作用の有無 を検討した．鉛作業者は 24 名を対像とし，血中鉛就上 び NK 活经, PHA 幼若化能を測定した.

<結果> $\mathrm{NK}$ 活性は $\mathrm{Li}_{2} \mathrm{CO}_{3}, \mathrm{SnCl}_{2} \mathrm{PbCl}_{2}, \mathrm{NiCl}_{2}$ で正常血中濃度の百倍以上でも变化を認めなかった。一 方, $\mathrm{CdCl}_{2}, \mathrm{CrCl}_{3}, \mathrm{DBTC}$ (ジブテルクロロ錫) は濃度 の增加とともに NK 活性は辢減した. $\mathrm{FeCl}_{3}$ は $1 \mathrm{mg} / \mathrm{ml}$ で急激な低下を示した. 24 時間の金属イオン含有培盖液 の影䠹は, $\mathrm{NiCl}_{2}$ \&不变, $\mathrm{Li}_{2} \mathrm{CO}_{3}, \mathrm{PbCl}_{2}, \mathrm{SnCl}_{2}$ で軽 度の上昇を示した. $\mathrm{CaCl}_{2}, \mathrm{CrCl}_{2}, \mathrm{FeCl}_{3}$ は不変であっ た、DBTC は著しい低下を示した，鉛作業者の血中鉛 量は $16.3 \pm 7.9 \mu \mathrm{g} / 100 \mathrm{~g}$ と刘照の $9.3 \pm 2.6 \mu \mathrm{g} / 100 \mathrm{~g}$
に比べ有意の高値を示した。NK 活性, および PHA 幼 若化能は有意差を認的なかった。をた血中鉛量とも有意 の相関関係を認めなかった。

〈考察〉発癌性を示唆されている $\mathrm{Cd}, \mathrm{Cr}$ のいずれも NK 活性堂低下させるが，NK 細胞と標的細胞の反応㭙 点て障害を支兄ることが示唆された。をた鉛イオンは NK 活性括よびPHA 幼若化能隹詨し通常影響を与兄ず, ヒト免疫系に対する影響を知るためには，さらに他種類 の金属の測定が必要と考光られた。

\section{5. 鉛暴露者における血中セレン量とグルタチオン} ペルオキシダーゼ活怪值の検討

新谷良英, 長尾文隆, 有流真由美 米澤隼男, 小森義隆, 血并 進 （大同病院）

伊藤宜則，大谷元彦

(名保衛大医衛生)

鈆取り扱い作業に従亨する男子製鋼作 業員, 年龄 18 歳から 59 歳の 687 名を対象として血中セレン量特よび 血中グルタチオンペルオキシダーゼ（以下 GSH-Px と 略記）活性を溳定し，これらの対象者の検診成績別飞比 較検討したので報告する.

対象事業所の作業環境は、気中鉿量が $91 \pm 61 \mu \mathrm{g} / \mathrm{m}^{3}$, 気中セレン量が $10.3 \pm 5.8 \mu \mathrm{g} / \mathrm{m}^{3}$ であり，作業者は 1 日8 時間勤務体制にあった。これら作業者について，そ の検診成績により, 価常者群 $(\mathrm{A})$, 肝機能検查異常者群 (B)，括ょび鉛検診異常者群 (C) 亿区分して比較した.

血中セレン量は(A)が $25.2 \pm 5.9 \mu \mathrm{g} / \mathrm{dl}$ ，(B) が 25.3 $\pm 5.7 \mu \mathrm{g} / \mathrm{dl}$, (C) には特飞差を認妨なった。しかしながら，鈆非取り报 い作業者では血中セレン量は $17.8 \pm 3.4 \mu \mathrm{g} / \mathrm{d} 1$ であり, 鉛取り扱い者が有意に高い成績をえた。

血中 GSH-Px 活㤬值は (A)が $24.4 \pm 6.0$ 単位, (B) が $23.3 \pm 6.2$ 単位, (C)が $26.6 \pm 7.7$ 単位であり, 肝 機能桧查異常者群で若干低〉, 逆に鉛㭲猃異常者群で高

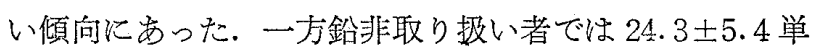
位を光，鉛取り扱い者との間には汪と儿ど差を認めなか った.

次に今回の対象者のうち健常者群では，血中セレン量 は加龄による变動を認めなかったが，GSH-Px 活性值は

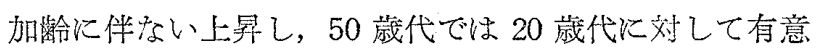
な高値をえた。またセレン量はプロトポルフィリン量执 よび $\delta$-ALA-D 活性值と特に鉛検診異常者群で負に相関 したが，GSH-Px 活性值は暴露歴，血中鉛量，プロトポ ルフィリン量， $\delta$-ALA-D 活性值などとの間に法有意な 相関性を認めなかった。 